Canadian Journal of Higher Education Revue canadienne d'enseignement supérieur

Volume 47, No. 2, 2017, pages 156 - 187

\title{
Postgraduate Wage Premiums and the Gender Wage Gap in Canada
}

Sean Waite

Western University

\begin{abstract}
Since the 1990s, enrolment in postgraduate programs has increased significantly in Canada. In more recent years, this has led to concerns regarding overproduction and the labour market outcomes of those with postgraduate education. Women have played an important role in this growth, but questions remain as to whether women's progress into the highest levels of education has helped ameliorate their wage disadvantage relative to men. Using the 2011 National Household Survey, this study finds large wage premiums for completing master's and doctoral degrees for both men and women, especially in younger cohorts; however, there are important differences by field of study. The gender wage gap is smaller for women with master's degrees than for those with bachelor or doctoral degrees. Occupational differences account for more of the gender wage gap than field of study, suggesting that after degree completion, university-educated women sort into occupations that are lower paid than their male counterparts'.
\end{abstract}

\section{Résumé}

Depuis les années 90, les inscriptions aux programmes de deuxième et de troisième cycles universitaires ont augmenté de façon importante au Canada. Récemment, des inquiétudes ont été exprimées quant à la surproduction de diplômés et à ses conséquences sur le marché du travail. Bien que les femmes aient occupé un rôle important dans l'augmentation de ces inscriptions, il 
est encore impossible de savoir si l'avancement de celles-ci vers les niveaux académiques les plus élevés a contribué à l'amélioration de leurs conditions salariales, par rapport à celles des hommes. À l'aide de l'Enquête nationale auprès des ménages 2011, la présente étude conclut que les salaires des femmes, tout comme ceux des hommes, sont bonifiés après l'obtention d'une maîtrise ou d'un doctorat, surtout chez les cohortes plus jeunes. Par contre, d'importantes variations existent en fonction du domaine d'étude. Pour les femmes possédant une maitrise, l'écart salarial entre sexes est moindre que pour les femmes possédant un baccalauréat ou un doctorat. L'écart salarial est davantage dû aux variantes sur le plan professionnel que celles des domaines d'étude, postulant donc qu'après avoir obtenu un diplôme universitaire, les femmes se lancent vers des professions moins rémunérées que ne le sont celles de leurs homologues masculins.

\section{Introduction}

Postgraduate education is an important human resource because it helps fuel innovation and development, both of which are essential in Canada's knowledge-driven economy. Over the last few decades, federal and provincial governments have recognized the value of postgraduate training and have made significant investments to encourage enrolment (AUCC, 2011; Hall \& Arnold, 2013). Between 1992/1993 and 2008/2009, full-time enrolment in master's programs increased by almost $80 \%$ and doctoral enrolment increased by more than 90\% (PSIS, 2016b). ${ }^{1}$ The number of postgraduate degrees granted increased in a similar fashion (PSIS, 2016a). Women have played a significant role in this growth (PSIS, 2016a, 2016b). However, not everyone sees these gains as positive. In recent years, questions have been raised regarding the employment opportunities and earnings for those who complete postgraduate degrees (Cyranoski, Gilbert, Ledford, Nayar, \& Yahira, 2011; Economist, 2010; Edge \& Munroe, 2015; Fullick, 2015)-specifically, whether or not postgraduate training provides any labour market advantages over a bachelor's degree. The present study contributes to this debate and also explores whether women's progress into postgraduate education has helped ameliorate their wage disadvantage relative to men.

To date, relatively few studies have explored the returns to postgraduate education. Much of the literature has relied on survey data from recent graduates, such as the Survey of Earned Doctorates (SED) or the National Graduate Survey (NGS) (e.g., Desjardins \& King, 2011; Ferguson \& Wang, 2014; King, Eisl-Culkin, \& Desjardins, 2008). For all the value of this literature, these studies do not provide a complete portrait of the returns to postgraduate education because they do not include information about older individuals with more work experience. At the same time, there is a dearth of literature exploring whether the gender wage gap attenuates as women progress beyond the bachelor's level. There has also been little research on the roles that field of study, occupation, and industry of employment play in terms of gender wage gaps at the undergraduate and postgraduate levels. Research on the gender wage gap for those with doctoral degrees has focused almost exclusively on university professors (Brown, Prentice, \& Troutt, 2007; Doucet, Durand, \& Smith, 2008; Doucet, Smith, \& Durand 2012; Guppy, 1989; Ornstein \& Stewart, 1996; Ornstein, Steward, \& Drakich, 1998, 2007; Sussman \& Yssaad, 2005; Warman, 
Woolley, \& Worswick, 2010); however, with fewer than 20\% of doctoral graduates finding work as full-time professors (Edge \& Munro, 2015), more research is needed on the earnings and gender wage gap for all those with postgraduate credentials.

This study bridges two important bodies of literature: the human capital literature on the economic returns to postsecondary education and the gender wage gap literature. First, I explore whether or not there is a postgraduate wage advantage above a bachelor's degree and how it varies by age, sex, and field of study. This contributes to classic economic literature, which suggests that investments in education will increase earnings (Becker, 1964). Much of the existing literature has relied on data collected on recent graduates. The absence of information on older respondents with more work experience is a problem if returns to education vary with duration in the labour market. To overcome this limitation, I use a large population-based survey that includes workers of all ages. The inclusion of both younger and older individuals will give a more complete portrait of returns to postgraduate education. I also look at how postgraduate wage premiums vary by age, sex, and field of study.

Next, I ask whether or not women who invest in postgraduate education are able to narrow the gender wage gap relative to women with bachelor's degrees. University education has played an important role in the attenuation of the gender wage gap (Baker \& Drolet, 2010; Fortin \& Huberman, 2002); however, there has been little research on whether the gender wage gap is smaller at the highest ends of the education spectrum. Again, the existing literature has relied on data collected on recent graduates to estimate wage gaps at the postgraduate level, which is problematic since women's wage disadvantage grows with duration in the labour market (Blau \& Kahn, 2000; Boudarbat \& Connolly, 2013; Finnie \& Wannell, 2004). By focusing on early labour market entrants, these studies are only able to speak to the gender wage gap at a period in the life cycle when women are the least disadvantaged relative to their male counterparts.

Lastly, gender differences in field of study have been identified as an important source of the gender wage gap for university graduates; however, it is unclear how large of a role field of study plays relative to occupational and industrial sorting. Women have made progress in the gender desegregation of some traditionally male fields (McMullen, Gilmore, \& Le Petit, 2010); however, if their increased representation in these fields has not corresponded to employment in concordant occupations, then field of study will play a much smaller role in explaining the gender wage gap than occupation or even industrial sorting. In other words, even when women have similar levels of education and degrees in identical fields of study, they may sort into lower-paid occupations relative to their male counterparts. This leads to the last research question, which asks what role differences in field of study, industry of employment and occupation play when it comes to explaining the gender wage gap for those with both undergraduate and postgraduate education.

To answer these questions, I use data from the 2011 National Household Survey (NHS). The NHS has many advantages over other surveys, including high-quality education, employment, and socio-demographic variables. Most importantly, the NHS is the most recent population-based survey containing a large enough sample of individuals with master's and doctoral degrees to meaningfully explore differences by age, sex, and field of study. Other surveys, such as the NGS and SED, only include information on recent graduates, and have small sample sizes and/or poor-quality employment and earnings variables. 


\section{Literature Review}

Since the early 1990 s there has been a significant increase in postgraduate enrolment and the number of postgraduate degrees granted in Canada (Hall \& Arnold, 2013; PSIS, 2016a, 2016b). ${ }^{2}$ Women have played a significant role in this growth. In 2008, the proportion of women graduating with a master's degree reached $54 \%$ (Turcotte, 2011). Female doctoral graduates also increased from 32\% in 1992 to $44 \%$ in 2008 (Turcotte, 2011). Other factors have also played a role in the growth of postgraduate enrolment. First, the provincial and federal governments have made significant investments in postgraduate funding through the implementation of scholarships and fellowships (Auriol, 2010; Hall \& Arnold, 2013; Industry Canada, 2002; Miller, Middaugh, \& Broniewicz, 2014; Wiggers, Lennon, \& Frank, 2011). Since fellowships and scholarships are a main source of financial support for postgraduate students (King et al., 2008), these investments have helped to offset foregone wages and other costs of postgraduate training. Second, the proportion of the population with a bachelor's degree has increased significantly since the 1990 (Turcotte, 2011). This may have created a situation where employers could demand greater credentials, even for jobs that did not require postgraduate skills or training. Third, as the supply of those with bachelor's degrees increased, so did competition. This may have also resulted in fewer employment opportunities for graduates at the bachelor's level. Fourth, recent opinion surveys show that only $13 \%$ of Canadians between the ages of 18 and 34 feel that they are better off than their parents, compared to $65 \%$ of the same age group in 1989 (Ipsos, 2016). Young adults may see postgraduate education as a means for upward social mobility. Lastly, young men at the end of the last century faced declining real wages (Beaudry \& Green, 2000), which may have increased the relative attractiveness of delaying labour market entry for higher education. The recent economic downturn may have had the same effect for graduates in the later 2000s (Ci, Frenette, \& Morissette, 2016; Ferguson \& Wang, 2014).

Another way Canada increases its supply of postgraduates is through immigration and foreign-earned degrees. As of 2006, 45\% of doctoral degrees were obtained outside Canada, either by Canadians travelling abroad for school or through immigration (King et al., 2008). ${ }^{3}$ Although this increase in postgraduate education is impressive, Canada still lags behind the United States in the actual production of doctorates (Hall \& Arnold, 2013; King et al., 2008; Pedersen, 2014). The overall proportion of the population with an earned doctorate degree is also smaller in Canada than in the United States (King et al., 2008).

While the growth in postgraduate education does not appear to be an exceptional case in Canada, there have been concerns regarding overproduction and the employment outcomes for those who complete postgraduate degrees (Cyranoski et.al., 2011; Economist, 2010; Edge \& Munroe, 2015; Fullick, 2015). Generally, employment rates increase with education. Recent estimates of postgraduate full-time employment rates are comparable to or even greater than those of bachelor degree graduates (Bayard \& Greenlee, 2009; Ferguson \& Wang, 2014). Desjardins and King (2011) used the SED and NGS to explore the employment outcomes of doctoral graduates from the 2005 graduating cohort. They found that two years after graduation, $80 \%$ of doctoral graduates had found paid work, another $5 \%$ were self-employed, and only $6 \%$ were unemployed. Of the $8 \%$ who were not in the labour market, the majority were still in school (Desjardins \& King, 2011, p. 27). 
There were, however, important differences by fields of study. For example, graduates from the humanities had a much higher unemployment rate of $16 \%$.

There is a well-documented wage advantage for completing a bachelor's degree in Canada (Boudarbat \& Connolly, 2013; Boudarbat, Lemieux, \& Riddell, 2010; Christie \& Shannon, 2001). Completing a postgraduate degree also provides a wage premium above the bachelor's level (Boudarbat et al., 2010). Using Canadian census data from 2006, the Association of Universities and Colleges of Canada estimated that the average annual earnings for someone holding a bachelor's degree was $\$ 71,300$, a master's $\$ 89,000$, and a doctorate $\$ 94,200$ (AUCC, 2011). These wage differences accumulate over the life span. Interestingly, the wage advantage for completing a master's degree over a bachelor's degree was far greater than the modest advantage for completing a doctorate over a master's degree (AUCC, 2011; Ferguson \& Wang, 2014). Using the 2005 cohort of the NGS, Bayard and Greenlee (2009) found that there was a 33\% wage premium for completing a master's degree over a bachelor's degree and only an extra $8 \%$ premium for completing a doctorate over a master's degree. This is interesting because the opportunity costs and forgone wages for completing a doctoral degree are far greater than they are for completing a master's degree.

To date, much of the literature interested in the labour market outcomes of postgraduates has focused on earned doctorates rather than master's degrees. This is likely due to data availability. In Canada, the SED provides insight into the labour market experiences of doctoral graduates shortly after graduating. There is no comparable dataset for those with master's degrees. The NGS is one option, but researchers using this survey typically focus on all university graduates or only on those with a bachelor's degree. Recently, Frenette and Frank (2016) used the 2011 NHS to compare age-adjusted earnings for full-time, full-year employees with college, bachelor's, and master's degrees. They found considerable variation in returns to field of study across all levels of education. Master's degrees in finance, financial services, business, and commerce had some of the highest earnings for both men and women. Theological and ministerial studies, social work, and library sciences had some of the lowest earnings for men. Women had some of the lowest earnings in theological and ministerial studies, student counselling, and linguistic studies.

Using SED and NGS data, Desjardins and King (2011) also explored the earnings of recent doctoral graduates. They found that two years after graduation, the median income for doctoral graduates was $\$ 65,000$; however, this concealed significant variation across broad fields of study. For example, graduates in life sciences (e.g., agricultural, biological, and health sciences) had the lowest median earnings. Humanities, computer sciences, mathematics, and physical sciences also had median earnings that were less than the average. Humanities stands out for having the lowest earnings, at the $75^{\text {th }}$ percentile, which suggests that there are few very high-paying jobs available for doctoral graduates in the humanities. Education and other related fields (e.g., business, management, public administration, architecture, law, communications) had the highest median earnings, suggesting that there are more opportunities to make very high salaries in these fields. Taken together, the employment rates and earnings for recent doctoral graduates are relatively positive; however, there are notable differences by field of study.

Gender remains an important dimension of labour market stratification in Canada. Since the 1960s, women have made significant strides in both educational attainment and labour force participation. Women's employment rates generally increase with education (Ferrao, 
2010; Morissette, Hou, \& Schellenberg, 2015). University-educated women have employment rates within three percent of men (Ferrao, 2010). This progress has helped narrow the gender wage gap (Baker \& Drolet, 2010; Fortin \& Huberman, 2002; Frenette \& Coulombe, 2007). However, women continue to earn less than men (Baker, Benjamin, Desaulniers, \& Grant, 1995; Baker \& Drolet, 2010; Drolet, 2002, 2009; Fortin \& Schirle, 2006).

Women's gains in educational attainment have been impressive, but women continue to be underrepresented in certain fields of study, such as science, technology, engineering, and mathematics (STEM) (Blickenstaff, 2005; McMullen et al., 2010). This is important because STEM fields tend to lead to jobs that are more highly paid than non-STEM fields, such as the arts or humanities (Bayard \& Greenlee, 2009; Christie \& Shannon, 1999; Fenesi \& Sana, 2015; Finnie \& Frenette, 2003; Frenette \& Frank, 2016). The sorting of women out of STEM and concordant occupations has been referred to as a leaky pipe-i.e., women leak out of STEM fields of study as they progress through the academic pipeline, and this continues when women transition from school to work (Blickenstaff, 2005). Accordingly, one would expect to see the fewest women in STEM at the postgraduate level, but this does not appear to be the case (Bayard \& Greenlee, 2009; Ferguson \& Wang, 2014). Bayard and Greenlee (2009) found the proportion of females in math, computer, architecture, engineering, and related technology fields increased with level of education. In other words, gender segregation was less pronounced at the postgraduate level than the bachelor level. This may result in a smaller gender wage gap at the postgraduate level of education.

Some studies have found smaller gender wage gaps for those with doctoral degrees (Bayard \& Greenlee, 2009; Desjardins \& King, 2011; Ferguson \& Wang, 2014). Using the most recent NGS data, Ferguson and Wang (2014) found that holding a doctoral degree was the great "equalizer" of wage differentials between men and women (p. 17). Although these findings paint an optimistic picture of the gender wage gap at the highest level of the education spectrum, they are unadjusted earnings for recent labour market entrants. Gender wage gaps also vary significantly by field of study (Desjardins \& King, 2011; Frenette \& Frank, 2016).

To date, the literature on the economic outcomes and gender wage gaps for those with postgraduate education is incomplete. One of the biggest constraints in the existing literature has been the use of data that only include information on recent graduates. This is also a problem for estimates of the gender wage gap, because wage trajectories for men and women are markedly different-i.e., wage gaps grow for women with their duration in the labour market. For this reason, estimates of the gender wage gap for recent graduates will not capture an accurate portrait of women's wage disadvantage. The existing studies have also been constrained by less than ideal employment variables and relatively few observations, making it difficult to control for highly disaggregated fields of study, occupation, and industry. To overcome these limitations, this study uses the 2011 NHS to explore whether there are postgraduate wage premiums and, if so, how they vary by sex, age, and field of study. I then ask whether the gender wage gap differs across degree type and examine the role played by differences in field of study, occupation, and industry of employment in explaining the gender wage gap. 


\section{Data}

This study uses the master sample of the 2011 Canadian NHS, which is a $33 \%$ sample of the entire Canadian population. The NHS was an optional survey with a response rate of $78.2 \%$. This response rate was significantly higher than both the NGS and the SED. ${ }^{4}$ Of those who completed the survey, $73.2 \%$ granted Statistics Canada permission to link the NHS with their income tax information.

The sample includes all those with a bachelor's degree or above, excluding doctors and lawyers. I exclude doctors and lawyers because earnings in these fields are significantly higher than in most others (Ferguson \& Wang, 2014). The type of training doctors and lawyers receive is also quite different than in other postgraduate programs. As well, a number of separate studies have looked at the employment outcomes and gender wage gaps of women in law (Dinovitzer, 2006, 2011; Dinovitzer \& Hagan, 2006; Kay, Masuch, \& Curry, 2004; Robson \& Wallace, 2001) and medicine (Baker, 1996; Connolly \& Holdcroft, 2006; Weeks \& Wallace, 2007a, 2007b). The sample includes employed individuals over the age of 25. Those under 25 are excluded because they may still be in school and not fully engaged in the labour market. I do not exclude older respondents who are working, because employment over the age of 65 may be more common for those with advanced degrees. ${ }^{5}$ Lastly, I exclude non-permanent residents and those residing in Nunavut, $\mathrm{Yu}$ kon, or the Northwest Territories, as the labour markets in these scarcely populated areas are very different from in the rest of Canada.

\section{Measures}

The dependent variable is the natural logarithm of total weekly employment income.Employment income includes all earnings received from wages and salaries, net income from incorporated non-farm business and/or professional practices, and net farm income. Income, rather than wages and salaries, is used to capture the various sources of remuneration that are common in occupations at the highest level of the education spectrum. Weekly income is calculated by dividing annual employment income by the total weeks worked in the previous year. A weekly income measure, rather than an hourly wage, is preferred for this analysis so the effect of hours worked can be analyzed.

Weeks worked is controlled by the construction of weekly earnings. I further control for whether the respondent was a paid employee or self-employed, and for hours worked.7,8 The NHS does not include a measure of work experience, so I use potential labour market experience, entered as the quartic function of the Mincer proxy (Lemieux, 2006; Murphy \& Welch, 1990). ${ }^{9,10}$ Field of study is coded using the two-digit series of the 2000 Classification of Instructional Programs (32 usable categories). ${ }^{11}$ To conserve space and for ease of interpretation, the primary field of study groupings (11 categories) is used in the descriptive tables and interaction models. I also control for degree (bachelor's, master's, or doctorate) and whether it was received outside of Canada. Occupation is coded using the 2011 National Occupational Classification for Statistics (NOC-S) major groups (40 categories). I also include a separate control for whether or not the individual was a university professor, since this has been a common occupation for those with doctoral degrees. Industry is coded using the 2007 North American Industrial Classification System industry sector (20 categories). All models also control for categorical age, the presence of children under 
the age of 15 in the household, marital status, urban/rural status, province of residence, knowledge of official language, aboriginal status, nativity, and visible minority status.

\section{Methods of Analysis}

Descriptive statistics are presented before the multivariate analysis. Ordinary least squares (OLS) regression is used with dummy variables for degree type (master's or doctoral degree). The reference category is a bachelor's degree. These models include all sociodemographic, human capital, field of study, industry, and occupation controls. Separate OLS models by age and sex are used to compare gender and age-group differences in postgraduate wage premiums. I then explore whether wage premiums for holding a postgraduate degree vary by field of study and sex after controlling for differences in characteristics. To do so, I run separate OLS models for men and women, including all controls, and then interact broad field of study (11 categories) with postgraduate degree (master's and doctoral degrees). The separate models for men and women help untangle differences by sex.

The next set of models explore the size and sources of the gender wage gap for women with postgraduate education in Canada. I start with a series of OLS models, with a dummy variable for sex. Model $a$ is the unadjusted or raw gender wage gap. Model $b$ includes socio-demographic, human-capital, and hours-worked variables. Model $c, d$, and $e$ systematically add controls for field of study (32 categories), industry, and occupation. The final model, $f$, includes an interaction term between gender and postgraduate degree to determine whether the gender wage gap is smaller at the master's or doctoral level. I also test for sample selection bias using Heckman two-step models.

To further investigate the sources of wage disadvantage, wage gaps are decomposed using Oaxaca-Blinder decompositions. Unlike ordinary least squares (OLS) models, decompositions do not pool coefficients. Separate models are run for each group, and wage gaps are separated into portions explained by differences in characteristics and differences in returns to these characteristics (Blinder, 1973; Jann, 2008; Oaxaca, 1973). It is common for the latter to be interpreted as a crude measure of discrimination; however, unexplained heterogeneity always remains a possible source of wage differentials (Rodgers, 2006). Relaxing the assumption that coefficients are fixed is helpful if we have reason to suspect that returns to coefficients differ between groups. I run a series of decomposition models with select variables to determine their individual contribution to the gender wage gap. I also decompose the fully specified models by age to see whether or not the determinants of the wage gaps vary by age group. Lastly, I run the same models for only those with postgraduate degrees to explore whether the sources of wage disadvantage are unique for those with postgraduate education. The cross-sectional design of this study does not allow me to infer causality from these results, but it does provide valuable insight into the returns to human capital and sources of the gender wage gap for university graduates at a particular moment in time.

\section{Results}

Table 1 presents the sample description. University-educated women outnumber men in the sample; however, a smaller proportion of women have master's and doctoral degrees. Women with university education are less likely to be married, have a foreign- 
earned degree, or be a first-generation Canadian, relative to university-educated men. They are also younger, work fewer hours per week, and are less likely to be self-employed than men. Women are also less likely to hold degrees in architecture, engineering, and related technologies, or in mathematics, computer and information sciences, or physical life sciences. University-educated women are concentrated in fields of study such as education, humanities, and health.

Table 1. Sample Description

\begin{tabular}{lcc}
\hline & Men & Women \\
\hline Bachelor's degree & 0.739 & 0.785 \\
Master's degree & 0.214 & 0.191 \\
Doctorate & 0.046 & 0.024 \\
Married & 0.636 & 0.561 \\
Young children & 0.362 & 0.369 \\
Self-employed & 0.124 & 0.073 \\
Hours worked (mean) & 40.288 & 36.336 \\
Age (mean) & 44.164 & 41.720 \\
CMA or CA & 0.926 & 0.903 \\
Aboriginal & 0.010 & 0.017 \\
Visible minority & 0.275 & 0.230 \\
First generation & 0.363 & 0.297 \\
Foreign degree & 0.251 & 0.198 \\
\hline Field of study & & \\
\hline Education & 0.081 & 0.204 \\
Visual and performing arts and communication & 0.025 & 0.034 \\
Humanities & 0.083 & 0.107 \\
Social and behavioural sciences & 0.136 & 0.173 \\
Business, management, and public administration & 0.234 & 0.191 \\
Physical and life sciences and technologies & 0.081 & 0.064 \\
Mathematics, computer, and information technology & 0.074 & 0.032 \\
Architecture, engineering, and related fields & 0.212 & 0.043 \\
Agriculture, natural resources, and conservation & 0.024 & 0.015 \\
Health, parks, recreation, and fitness & 0.045 & 0.134 \\
Personal, protective, and transportation & 0.004 & 0.001 \\
$N$ & 386,260 & 424,865 \\
\hline & & \\
& & 0.04 \\
\hline
\end{tabular}

Source: 2011 National Household Survey. Notes: Sample includes those with bachelor's, master's, and doctoral degrees, over the age of 25 , with annual incomes greater than $\$ 1.00$. The sample excludes those with law or medical degrees, non-permanent residents, and those residing in the Northwest Territories, the Yukon, or Nunavut. 
Table 2 presents mean weekly earnings by degree type, field of study, age, and sex. This table provides descriptive insight into the first research question, which asks whether or not there is a postgraduate wage advantage and, if so, how it varies by age, sex, and field of study. To conserve space, I use the 11 primary field of study categories, as opposed to the 32 categories. I present the difference in weekly earnings relative to the weekly earnings of someone with a bachelor's degree, by age and sex. Visual and performing arts and communications, as well as the humanities, have much lower weekly earnings at both the bachelor's and postgraduate levels, relative to the average weekly earnings for a bachelor's degree. In some cases, even those with doctorates in these fields have lower earnings than the average earnings of someone with a bachelor's degree. The agriculture, natural resources, and conservation fields also have lower earnings at the postgraduate level. Conversely, business, management, and public administration have the greatest wage premiums. For example, younger men with master's degrees in business, management, and public relations have weekly earnings that are \$633 more than the average earnings of others with a bachelor's degree. Women also have very large premiums in business, management, and administration. Sensitivity models indicate this is driven by those with masters of business administration (MBA) degrees, who are typically very highly paid. Older men with a doctorate degree in business, management, and administration have a much lower wage premium than those who completed a master's degree (\$519 vs. \$1,107). Again, this is the result of MBA graduates, some of whom work as senior managers or executives and have very high earnings. Those who complete a doctoral degree in business, management, and public administration are more likely working as professors, where the opportunities to earn very high incomes are somewhat limited by wage setting guidelines in university collective agreements. ${ }^{12}$ Wage premiums are smaller for the younger cohorts, which suggests that either the wage advantage for postgraduate education grows with duration in the labour market or recent graduates are not doing as well. Women's weekly earnings are smaller than men's, but in many cases postgraduate education increases women's earnings more than men's, which suggests that postgraduate trainings may help narrow the gender wage gap.

Table 3 uses multivariate ordinary least squares (OLS) models to explore whether the patterns observed in the descriptive tables hold after controlling for known determinants of wages. Separate models are run by sex and age, with dummy variables for degree type. Although these are the fully specified models with all controls, I report select coefficients only. ${ }^{13}$ The reference category is bachelor's degree. The results for the entire sample show that there was a significant wage advantage for completing a master's and doctoral degree, relative to a bachelor's degree. For men there was a $4 \%$ wage premium for completing a master's degree and a 14\% premium for completing a doctoral degree, over a bachelor's degree (calculated using (e $\left.\beta-1)^{*} 100\right)$. For women, the wage premiums were even larger. Women with a master's degree earned $7 \%$ more than those with a bachelor's degree, and those with a doctoral degree earned $18 \%$ more. Younger cohorts had even larger wage advantages for completing a postgraduate degree than older cohorts. In fact, older men with a master's degree had no earnings advantage relative to those with bachelor's degrees. Interestingly, this was statistically significant in sensitivity models excluding those over the age of 65. This means that men with master's degrees who are over the age of 65 are not making as much money as men over the age of 65 with bachelor's degrees. Perhaps the 
type of work older men with master's degrees engage in is more leisurely than what men with only a bachelor's degree do. It could be that the greater lifetime earnings for men with master's degrees allows them to worry less about wage maximization in later years. It is also possible that the distinction between a bachelor's and a master's degree matters less in later years because other factors, such as work experience, skills, and training, are better indicators of productivity for men at the end of their careers than educational credentials.

Table 2. Mean Weekly Earning Differences Relative to the Average of all Bachelor's Degree Fields, by Age Group and Sex

\begin{tabular}{|c|c|c|c|c|}
\hline & \multicolumn{2}{|c|}{25 to 45 years old } & \multicolumn{2}{|c|}{ Over 45 years old } \\
\hline & Men & Women & Men & Women \\
\hline \multicolumn{5}{|l|}{ Bachelor's Degree } \\
\hline All fields (reference) & $\$ 1,491$ & $\$ 1,147$ & $\$ 2,042$ & $\$ 1,350$ \\
\hline Education & $-\$ 179$ & $-\$ 10$ & $-\$ 602$ & $-\$ 29$ \\
\hline Visual and performing arts and communication & $-\$ 454$ & $-\$ 303$ & $-\$ 816$ & $-\$ 341$ \\
\hline Humanities & $-\$ 272$ & $-\$ 168$ & $-\$ 518$ & $-\$ 91$ \\
\hline Social and behavioural sciences & $-\$ 108$ & $-\$ 95$ & $-\$ 110$ & $-\$ 75$ \\
\hline Business, management, and public administration & $\$ 229$ & $\$ 128$ & $\$ 444$ & $\$ 137$ \\
\hline Physical and life sciences and technologies & $-\$ 45$ & $-\$ 55$ & $-\$ 5$ & $-\$ 26$ \\
\hline Mathematics, computer, and information technology & $-\$ 28$ & $\$ 85$ & $-\$ 91$ & $\$ 132$ \\
\hline Architecture, engineering, and related fields & $\$ 119$ & $\$ 136$ & $\$ 285$ & $-\$ 15$ \\
\hline Agriculture, natural resources, and conservation & $-\$ 104$ & $-\$ 101$ & $-\$ 562$ & $-\$ 85$ \\
\hline Health, parks, recreation, and fitness & $-\$ 58$ & $\$ 137$ & $-\$ 193$ & $\$ 126$ \\
\hline Personal, protective, and transportation & $-\$ 96$ & $\$ 136$ & $-\$ 452$ & $-\$ 99$ \\
\hline \multicolumn{5}{|l|}{ Master's Degree } \\
\hline All fields & $\$ 168$ & $\$ 114$ & $\$ 264$ & $\$ 209$ \\
\hline Education & $\$ 49$ & $\$ 109$ & $-\$ 346$ & $\$ 171$ \\
\hline Visual and performing arts and communication & $-\$ 426$ & $-\$ 382$ & $-\$ 483$ & $-\$ 330$ \\
\hline Humanities & $-\$ 383$ & $-\$ 165$ & $-\$ 740$ & $-\$ 144$ \\
\hline Social and behavioural sciences & $-\$ 125$ & $-\$ 36$ & $\$ 23$ & $\$ 98$ \\
\hline Business, management, and public administration & $\$ 633$ & $\$ 415$ & $\$ 1,107$ & $\$ 575$ \\
\hline Physical and life sciences and technologies & $-\$ 29$ & $-\$ 56$ & $\$ 137$ & $\$ 138$ \\
\hline Mathematics, computer, and information tech. & $-\$ 47$ & $\$ 97$ & $\$ 107$ & $\$ 186$ \\
\hline Architecture, engineering, and related fields & $\$ 156$ & $\$ 188$ & $\$ 277$ & $\$ 253$ \\
\hline Agriculture, natural resources, and conservation & $-\$ 202$ & $\$ 56$ & $-\$ 362$ & $-\$ 32$ \\
\hline Health, parks, recreation, and fitness & $-\$ 121$ & $\$ 165$ & $-\$ 140$ & $\$ 314$ \\
\hline Personal, protective, and transportation & $\$ 226$ & $\$ 79$ & $-\$ 119$ & $\$ 339$ \\
\hline
\end{tabular}




\begin{tabular}{lrrrr}
\hline & \multicolumn{2}{c}{ 25 to 45 years old } & \multicolumn{2}{c}{ Over 45 years old } \\
\cline { 2 - 5 } & Men & Women & Men & Women \\
\hline Doctorate & & & & \\
\hline All fields & $\$ 157$ & $\$ 255$ & $\$ 223$ & $\$ 453$ \\
Education & $-\$ 31$ & $\$ 285$ & $\$ 15$ & $\$ 491$ \\
Visual and performing arts and communication & $-\$ 331$ & $-\$ 172$ & $-\$ 202$ & $\$ 269$ \\
Humanities & $-\$ 79$ & $\$ 227$ & $\$ 27$ & $\$ 436$ \\
Social and behavioural sciences & $\$ 283$ & $\$ 270$ & $-\$ 21$ & $\$ 470$ \\
Business, management, and public administration & $\$ 656$ & $\$ 756$ & $\$ 519$ & $\$ 583$ \\
Physical and life sciences and technologies & $\$ 143$ & $\$ 114$ & $\$ 351$ & $\$ 427$ \\
Mathematics, computer, and information tech. & $\$ 260$ & $\$ 412$ & $\$ 313$ & $\$ 578$ \\
Architecture, engineering, and related fields & $\$ 224$ & $\$ 358$ & $\$ 447$ & $\$ 349$ \\
Agriculture, natural resources, and conservation & $-\$ 161$ & $\$ 128$ & $-\$ 354$ & $\$ 79$ \\
Health, parks, recreation, and fitness & $-\$ 23$ & $\$ 350$ & $\$ 359$ & $\$ 483$ \\
Personal, protective, and transportation & $\dagger$ & $\dagger$ & $\dagger$ & $\dagger$ \\
$N$ & & & & \\
& 212,355 & 268,230 & 173,910 & 156,640 \\
\hline
\end{tabular}

Source: 2011 National Household Survey. Notes: Sample includes those with university degrees, over the age of 25, with annual incomes greater than $\$ 1.00$. The sample excludes those with law or medical degrees, non-permanent residences, and those residing in the Northwest Territories, the Yukon, or Nunavut. † sample sizes too small for reliable estimates.

Table 3.Wage Premiums for Postgraduate Education by Age and Sex (ref: Bachelor's Degree)

\begin{tabular}{lccc}
\hline & All & 25 to 45 years old & Over 45 years old \\
\hline Men & & & \\
\hline Master's degree & $0.041^{* * *}$ & $0.079^{* * *}$ & 0.010 \\
Doctorate & $0.129^{* * *}$ & $0.189^{* * *}$ & $0.086^{* * *}$ \\
Constant & $5.801^{* * *}$ & $5.843^{* * *}$ & $7.339^{* * *}$ \\
$R$-squared & $0.277^{* *}$ & 0.291 & 0.273 \\
$N$ & 386,260 & 212,355 & 173,910 \\
\hline Women & & & $0.068^{* * *}$ \\
Master's degree & $0.070^{* * *}$ & $0.076^{* * *}$ & $0.162^{* * *}$ \\
Doctorate & $0.169^{* * *}$ & $0.176^{* * *}$ & $6.902^{* * *}$ \\
Constant & $5.811^{* * *}$ & $5 \cdot 769^{* * *}$ & 0.284 \\
$R$-squared & 0.272 & 0.262 & 156,640 \\
$N$ & 424,865 & 268,230 & \\
\hline
\end{tabular}

Source: 2011 National Household Survey. ${ }^{*} \mathrm{P} \leq .05 ;{ }^{*} \mathrm{P} \leq .01 ;{ }^{* *} \mathrm{P} \leq .001$. Sample includes those with university degrees, over the age of 25 , with annual incomes greater than $\$ 1.00$. The sample excludes those with law or medical degrees, non-permanent residents, and those residing in the Northwest Territories, the Yukon, or Nunavut. These models also control for categorical age, marital status, presence of children in the household, province of residence, urban residence, self-employment, a quartic of potential experience (Mincer, Mincer ${ }^{\wedge} 2$, Mincer $^{\wedge} 3$, Mincer ${ }^{\wedge} 4$ ), knowledge of official language, aboriginal status, visible minority, immigrant, foreign earned degree, field of study (32 categories) industry (20 categories), and occupation (40 categories). The reference category is bachelor's degree. 
The results from Table 3 also include coefficients that are relevant for the gender wage gap analysis, such as the effects of marriage and parenthood. These models include all control variables and are available in Appendix Table B. Previous studies have found that marriage increased men's and women's earnings (more so for men), and parenthood increased men's earnings but decreased women's (Budig \& England, 2001; Budig \& Hodges, 2010; Hodges \& Budig, 2010; Killewald, 2012; Killewald \& Gough, 2013; Waldfogel, 1998; Zhang, 2009). These parenthood effects are referred to as the fatherhood premium and motherhood penalty. Appendix Table B shows that being married rather than single increased men's earnings by roughly $12 \%$, and the presence of children ( $<$ age 15$)$ further increased men's earnings by $4.5 \%$. Marriage had no effect on women's earnings, and having children provided a wage penalty of $3 \%$ for university-educated women. Parenthood effects were stronger for the younger group, with fatherhood premiums increasing men's earnings by roughly $9 \%$ and motherhood penalties decreasing women's earnings by $4 \%$.

To explore field-of-study differences in returns to postgraduate education, I ran separate OLS models for men and women, including all controls and introducing an interaction term between postgraduate degree and field of study (Table 4). I used broad field of study and collapsed master's and doctoral degrees into a single postgraduate category. The field of study reference category was education. The base models show how returns to university education varied by field of study. In all but one case, the direction of the coefficients was identical for men and women, although they did vary in magnitude. The one exception was for women in architecture, engineering, and related fields, who earned less than women in education. Men, on the other hand, earned more in architecture, engineering, and related fields than those in education. This is because women are more likely to work in lower-paid architectural jobs than in engineering, while men have greater numbers in higher-paid engineering. These base models are interesting, but they do not reveal whether postgraduate wage premiums are greater in some fields than others. For example, previous studies have found less positive employment outcomes for humanities graduates (Fenesi \& Sana, 2015). The second models include the interaction terms between field of study and postgraduate degree. Significant and positive interactions indicate that the postgraduate wage premium is greater in a particular field, while a significant and negative interaction indicates that the postgraduate wage premium is less in that field. For men, there is little variation across fields of study in the postgraduate wage premium. Men can expect larger postgraduate wage premiums in social and behavioural sciences as well as business, management, and public administration. Both men and women can expect smaller postgraduate wage premiums in humanities. Women also have smaller postgraduate wage premiums in visual and performing arts, physical and life sciences, and architecture and engineering. The only field of study where, for women, the wage premium for completing a postgraduate degree is greater than in education is business, management, and public administration.

Table 5 answers the second research question regarding the size of the gender wage gap for those with university degrees and whether or not this gap narrows at the master's and doctoral level. To answer this question, I use a series of multivariate OLS models with a dichotomous sex variable. I also run separate models by age group. Model $a$ is the unadjusted or raw gender wage gap. Model $b$ includes socio-demographic, human capital, and hours worked variables. Models $c, d$, and $e$ systematically add controls for field of study 
( 32 categories), industry ( 20 categories), and occupation (40 categories). The final model, $f$, includes an interaction term between gender and degree type to determine whether the gender wage gap is smaller for those with either a master's or a doctoral education, relative to those with a bachelor's degree, after controlling for known determinants of wages. Heckman models are used to test for sample selection bias. Since there was very little change in these estimates, I only present the OLS results. ${ }^{14}$

Table 4. OLS Regressions with Postgraduate Degree and Field of Study Interaction

\begin{tabular}{|c|c|c|c|c|}
\hline & \multicolumn{2}{|c|}{ Men } & \multicolumn{2}{|c|}{ Women } \\
\hline & Base & Interaction & Base & Interaction \\
\hline Master's or doctoral degree & $0.040^{* * *}$ & 0.019 & $0.071^{* * *}$ & $0.075^{* * *}$ \\
\hline $\begin{array}{l}\text { Visual and performing arts and } \\
\text { communication }\end{array}$ & $-0.127^{* * *}$ & $-0.132^{* * *}$ & $-0.160^{* * *}$ & $-0.143^{* * *}$ \\
\hline Humanities & $-0.103^{* * *}$ & $-0.087^{* * *}$ & $-0.091^{* * *}$ & $-0.081^{* * *}$ \\
\hline Social and behavioural sciences & -0.018 & $-0.029^{* *}$ & $-0.045^{* * *}$ & $-0.047^{* * *}$ \\
\hline $\begin{array}{l}\text { Business, management, and public } \\
\text { administration }\end{array}$ & $0.090^{* * *}$ & $0.073^{* * *}$ & $0.031^{* * *}$ & $0.024^{* *}$ \\
\hline $\begin{array}{l}\text { Physical and life sciences and } \\
\text { technologies }\end{array}$ & -0.017 & -0.013 & $-0.074^{* * *}$ & $-0.061^{* * *}$ \\
\hline $\begin{array}{l}\text { Mathematics, computer, and } \\
\text { information tech. }\end{array}$ & $0.022^{*}$ & 0.015 & $0.023^{*}$ & 0.015 \\
\hline $\begin{array}{l}\text { Architecture, engineering, and re- } \\
\text { lated fields }\end{array}$ & $0.062^{* * *}$ & $0.063^{* * *}$ & $-0.022^{*}$ & -0.011 \\
\hline $\begin{array}{l}\text { Agriculture, natural resources, and } \\
\text { conservation }\end{array}$ & $-0.050^{* * *}$ & $-0.048^{* *}$ & $-0.112^{* * *}$ & $-0.110^{* * *}$ \\
\hline Health, parks, recreation, and fitness & 0.016 & 0.016 & $0.046^{* * *}$ & $0.051^{* * *}$ \\
\hline $\begin{array}{l}\text { Personal, protective, and } \\
\text { transportation }\end{array}$ & $0.062^{*}$ & $0.071^{* *}$ & $0.067^{*}$ & 0.064 \\
\hline
\end{tabular}

Postgraduate degree and field of study interaction

Visual and performing arts and communication

Humanities

Social and behavioural sciences

$\begin{array}{cc}0.023 & -0.087^{* *} \\ -0.055^{* *} & -0.046^{* *} \\ 0.050^{* *} & 0.010 \\ 0.063^{* * *} & 0.036^{* *} \\ -0.003 & -0.045^{* *} \\ 0.032 & 0.022 \\ 0.002 & -0.040^{*} \\ 0.000 & -0.007 \\ 0.000 & -0.018\end{array}$

Business, management, and public administration

Physical and life sciences and technologies

Mathematics, computer, and information tech.

Architecture, engineering, and related fields

Agriculture, natural resources, and conservation

Health, parks, recreation, and fitness

0.000

$-0.018$ 


\begin{tabular}{lcccc}
\hline & \multicolumn{2}{c}{ Men } & \multicolumn{2}{c}{ Women } \\
\cline { 2 - 5 } & Base & Interaction & Base & Interaction \\
\hline $\begin{array}{l}\text { Personal, protective, and } \\
\quad \text { transportation }\end{array}$ & & -0.035 & & 0.020 \\
Constant & $5.799^{* * *}$ & $5.805^{* * *}$ & $5.807^{* * *}$ & $5.808^{* * *}$ \\
$R$-squared & 0.276 & 0.277 & 0.27 & 0.271 \\
$N$ & 386,260 & 386,260 & 424,865 & 424,865 \\
\hline
\end{tabular}

Source: 2011 National Household Survey. ${ }^{*} \mathrm{P} \leq .05 ;{ }^{* *} \mathrm{P} \leq .01 ;{ }^{* * *} \mathrm{P} \leq .001$. Sample includes those with university degrees, over the age of 25 , with annual incomes greater than $\$ 1.00$. The sample excludes those with law or medical degrees, non-permanent residents, and those residing in the Northwest Territories, the Yukon, or Nunavut. These models also control for categorical age, marital status, presence of children in the household, province of residence, urban residence, self-employment, a quartic of potential experience (Mincer, Mincer^2, ${ }^{\wedge i n c e r}{ }^{\wedge} 3$, Mincer^${ }^{\wedge} 4$ ), knowledge of official language, aboriginal status, visible minority, immigrant, foreign earned degree, industry, occupation, and whether the person was a professor. The reference categories are: bachelor's degree and education.

Table 5. OLS Gender Wage Gaps for University Graduates by Age Groups

\begin{tabular}{|c|c|c|c|c|c|c|}
\hline & $\mathrm{a}$ & $\mathrm{b}$ & $\mathrm{c}$ & $\mathrm{d}$ & $\mathrm{e}$ & $\mathrm{f}$ \\
\hline \multicolumn{7}{|l|}{ All Ages } \\
\hline Women & $-0.245^{* * *}$ & $-0.186^{* * *}$ & $-0.148^{* * *}$ & $-0.142^{* * * *}$ & $-0.120^{* * * *}$ & $-0.128^{* * *}$ \\
\hline Master's & & $0.122^{* * *}$ & $0.128 * * *$ & $0.108^{* * *}$ & $0.057^{* * *}$ & $0.041^{* * *}$ \\
\hline Doctorate & & $0.208^{* * *}$ & $0.242^{* * *}$ & $0.216^{* * *}$ & $0.149^{* * *}$ & $0.142^{* * *}$ \\
\hline $\begin{array}{l}\text { Field of study (32 } \\
\text { categories) }\end{array}$ & & & $\mathrm{x}$ & $\mathrm{x}$ & $\mathrm{x}$ & $\mathrm{x}$ \\
\hline $\begin{array}{l}\text { Industry (20 catego- } \\
\text { ries) }\end{array}$ & & & & $\mathrm{x}$ & $\mathrm{x}$ & $\mathrm{x}$ \\
\hline $\begin{array}{l}\text { Occupation (40 cat- } \\
\text { egories) }\end{array}$ & & & & & $\mathrm{x}$ & $\mathrm{x}$ \\
\hline $\begin{array}{l}\text { Master's degree } \mathrm{x} \\
\text { women }\end{array}$ & & & & & & $0.030^{* * * *}$ \\
\hline Doctorate $\mathrm{x}$ women & & & & & & 0.019 \\
\hline Constant & $7.045^{* * *}$ & $5.646^{* * *}$ & $5.633^{* * *}$ & $5 \cdot 714^{* * *}$ & $5.887^{* * *}$ & $5.890^{* * *}$ \\
\hline$R$-squared & 0.016 & 0.185 & 0.205 & 0.235 & 0.281 & 0.281 \\
\hline \multirow[t]{2}{*}{$N$} & 811,130 & 811,130 & 811,130 & 811,130 & 811,130 & 811,130 \\
\hline & $\mathrm{a}$ & $\mathrm{b}$ & $\mathrm{c}$ & $\mathrm{d}$ & $\mathrm{e}$ & $\mathrm{f}$ \\
\hline \multicolumn{7}{|l|}{25 to 45 years old } \\
\hline Women & $-0.238^{* * *}$ & $-0.165^{* * *}$ & $-0.132^{* * *}$ & $-0.124^{* * *}$ & $-0.106^{* * *}$ & $-0.111^{* * *}$ \\
\hline Master's & & $0.140^{* * *}$ & $0.141^{* * *}$ & $0.124^{* * *}$ & $0.079^{* * *}$ & $0.069^{* * *}$ \\
\hline Doctorate & & $0.222^{* * *}$ & $0.250^{* * *}$ & $0.235^{* * *}$ & $0.178^{* * *}$ & $0.163^{* * *}$ \\
\hline $\begin{array}{l}\text { Field of study ( } 32 \\
\text { categories) }\end{array}$ & & & $\mathrm{x}$ & $\mathrm{x}$ & $\mathrm{x}$ & $\mathrm{x}$ \\
\hline $\begin{array}{l}\text { Industry (20 catego- } \\
\text { ries) }\end{array}$ & & & & $\mathrm{x}$ & $\mathrm{x}$ & $\mathrm{x}$ \\
\hline
\end{tabular}




\begin{tabular}{|c|c|c|c|c|c|c|}
\hline & $\mathrm{a}$ & $\mathrm{b}$ & $\mathrm{c}$ & $\mathrm{d}$ & $\mathrm{e}$ & $f$ \\
\hline $\begin{array}{l}\text { Occupation (40 cat- } \\
\text { egories) }\end{array}$ & & & & & $\mathrm{x}$ & $\mathrm{x}$ \\
\hline $\begin{array}{l}\text { Master's degree x } \\
\text { women }\end{array}$ & & & & & & $0.018^{*}$ \\
\hline Doctorate $\mathrm{x}$ women & & & & & & 0.034 \\
\hline Constant & $6.994^{* * *}$ & $5 \cdot 597^{* * *}$ & $5.622^{* * *}$ & $5.698^{* * *}$ & $5.851^{* * *}$ & $5.853^{* * *}$ \\
\hline$R$-squared & 0.018 & 0.184 & 0.208 & 0.237 & 0.281 & 0.281 \\
\hline \multirow[t]{2}{*}{$N$} & 480,585 & 480,585 & 480,585 & 480,585 & 480,585 & 480,585 \\
\hline & $\mathrm{a}$ & $\mathrm{b}$ & $\mathrm{c}$ & $\mathrm{d}$ & $\mathrm{e}$ & $\mathrm{f}$ \\
\hline \multicolumn{7}{|l|}{ Over 45 years old } \\
\hline Women & $-0.231^{* * *}$ & $-0.219^{* * *}$ & $-0.173^{* * *}$ & $-0.169^{* * *}$ & $-0.141^{* * *}$ & $-0.154^{* * *}$ \\
\hline Master's & & $0.102^{* * *}$ & $0.118 * * *$ & $0.095^{* * *}$ & $0.036^{* * *}$ & 0.014 \\
\hline Doctorate & & $0.189^{* * *}$ & $0.232^{* * *}$ & $0.196^{* * *}$ & $0.119^{* * *}$ & $0.109^{* * *}$ \\
\hline $\begin{array}{l}\text { Field of study ( } 32 \\
\text { categories) }\end{array}$ & & & $\mathrm{x}$ & $\mathrm{x}$ & $\mathrm{x}$ & $\mathrm{x}$ \\
\hline $\begin{array}{l}\text { Industry (20 catego- } \\
\text { ries) }\end{array}$ & & & & $\mathrm{x}$ & $\mathrm{x}$ & $\mathrm{x}$ \\
\hline $\begin{array}{l}\text { Occupation (40 cat- } \\
\text { egories) }\end{array}$ & & & & & $\mathrm{x}$ & $\mathrm{x}$ \\
\hline $\begin{array}{l}\text { Master's degree x } \\
\text { women }\end{array}$ & & & & & & $0.049^{* * *}$ \\
\hline Doctorate $\mathrm{x}$ women & & & & & & 0.030 \\
\hline Constant & $7.110^{* * *}$ & $6.955^{* * *}$ & $6.936^{* * *}$ & $6.904^{* * *}$ & $7.208^{* * *}$ & $7.208^{* * *}$ \\
\hline$R$-squared & 0.012 & 0.180 & 0.198 & 0.230 & 0.282 & 0.282 \\
\hline$N$ & 330,545 & 330,545 & 330,545 & 330,545 & 330,545 & 330,545 \\
\hline
\end{tabular}

Source: 2011 National Household Survey. ${ }^{*} \mathrm{P} \leq .05 ;{ }^{* *} \mathrm{P} \leq .01 ; * * * \mathrm{P} \leq .001$. Sample includes those with university degrees, over the age of 25 , with annual incomes greater than $\$ 1.00$. The sample excludes those with law or medical degrees, non-permanent residents, and those residing in the Northwest Territories, the Yukon, or Nunavut. Notes: Models b through $\mathrm{f}$ also control for categorical age, marital status, presence of children in the household, province of residence, urban residence, self-employment, a quartic of potential experience (Mincer, Mincer ${ }^{\wedge} 2$, Minc$\mathrm{er}^{\wedge} 3$, Mincer^ 4 ), knowledge of official language, aboriginal status, visible minority, immigrant, and foreign-earned degree. Models $\mathrm{c}$ through $\mathrm{f}$ also control for whether the individual was working as a professor. The reference category is bachelor's degree.

The unadjusted gender wage gap is $22 \%$. This is reduced to $17 \%$ in model $b$ after controlling for socio-demographic, human capital, and hours worked variables. Adding field of study (32 categories) further narrows the gender wage gap to 14\%. Controlling for industry narrows the gender wage gap by an additional one percentage point, and occupations further narrows the gap by two percentage points. In the fully specified model, the gender wage gap for those with a university degree is $11 \%$. Wage gaps are generally smaller for the younger group than for the older one. For example, younger women with a university education have a gender wage gap of 10\%, while older university-educated women have a gender wage gap of $14 \%$. 
To explore whether the gender wage gap is smaller for those with a postgraduate degree, I include an interaction term between sex and master's and doctoral degrees. A statistically significant and positive interaction indicates that the wage gap is smaller, whereas a statistically significant and negative interaction indicates that wage gaps are larger. The results show that holding a master's degree reduces the gender wage gap by a further three percentage points, relative to the bachelor group. The interaction for doctoral degree was not significant, which indicates that the gender wage gap for those holding doctorates is comparable to what occurs for those with a bachelor's degree. This pattern holds across both age groups. For the older age group, holding a master's degree narrows the gender wage gap by an additional five percentage points relative to the bachelor level. One explanation may be higher rates of public sector employment for women with master's degrees. ${ }^{15}$ An analysis of the NOC-S minor occupations showed a greater proportion of women with master's degrees working in education as secondary school teachers, vice-principals, principals, and instructors in community colleges. These are generally public sector jobs. Public sector employment tends to have higher rates of unionization, more rigid wage-setting practices, less discretionary pay, and more firmly entrenched equality legislation, all of which help to reduce wage inequality for women and minorities(Baker \& Fortin, 2004; Hou \& Coulombe, 2010; Mandel \& Semyonov, 2014; Waite \& Denier, 2015).

Tables 6 and 7 address the final research question, which explores the roles that field of study, industry of employment, and occupation have in explaining the gender wage gaps for university graduates. I also ran identical models restricting the sample to those with master's and doctoral degrees, to see whether the sources of wage disadvantage are unique at the postgraduate level. There was very little difference in these estimates; they are available in Appendix Tables $\mathrm{C}$ and D. Oaxaca-Blinder decompositions are used to explore the individual and combined effects of select variables on the gender wage gap. To conserve space, I only provide the unadjusted or raw wage gap, the portion explained by differences in characteristics (explained) and differences in returns to characteristics (unexplained) between men and women. For ease of interpretation, I provide the overall percentages explained and unexplained. Model $a$ includes all socio-demographic variables as well as experience, degree type, professor, and foreign-earned degree. These characteristics collectively advantage university-educated women. This is due to differences in self-employment, foreign-earned degrees, and ethno-linguistic differences. In other words, there are fewer women with foreign-earned degrees and women who are self-employed, which both decrease earnings. Adding a control for hours worked explains a sizable portion of the gender wage gap (model $b$ ). In fact, differences in hours worked explain roughly $29 \%$ of the gender wage gap for all university graduates (see Table 7 ). Models $c, d$, and $e$ control for either field of study (32 categories), industry (20 categories), or occupation (40 categories). The objective here is to explore the independent effect of each of these characteristics on the gender wage gap. Field of study and industry of employment independently explained $3 \%$ of the gender wage gap, whereas occupation explained $26 \%$ of the gap. ${ }^{16}$ The fully specified model explains just under $48 \%$ of the overall gender wage gap. This leaves $52 \%$ of the gender wage gap unexplained. As well, there are some differences by age. The raw wage gap is slightly larger for the younger group, but a greater proportion of this can be explained by differences in characteristics. 
Table 7 presents the complete results of the decompositions from the fully specified models by age group in Table 6 (Models $f, g$, and $h$ ). Differences in field of study were not significant determinants of the gender wage gap for those with a university education. Differences in self-employment, ethno-linguistic characteristics, and the possession of foreign-earned degree advantaged women relative to men, whereas, hours worked, occupation, and industry of employment were important sources of wage disadvantage.

Table 6. Decomposition of Gender Wage Gap for all University Graduates

\begin{tabular}{|c|c|c|c|c|c|}
\hline & Gap & Explained & $\begin{array}{c}\text { \% of Overall } \\
\text { Gap Explained }\end{array}$ & Unexplained & $\begin{array}{l}\text { \% of Overall } \\
\text { Gap } \\
\text { Unexplained }\end{array}$ \\
\hline $\begin{array}{l}\text { Model a: Socio- } \\
\text { demographics }{ }^{\dagger}\end{array}$ & $-0.245^{* * *}$ & $0.036^{* * *}$ & $-15 \%$ & $-0.281^{* * *}$ & $115 \%$ \\
\hline $\begin{array}{l}\text { Model } b \text { : Socio- } \\
\text { demographics }{ }^{\dagger} \\
\text { and hours worked }\end{array}$ & $-0.245^{* * *}$ & $-0.062^{* * *}$ & $25 \%$ & $-0.183^{* * *}$ & $75 \%$ \\
\hline $\begin{array}{l}\text { Model } c \text { : Field of } \\
\text { study ( } 32 \text { catego- } \\
\text { ries) }\end{array}$ & $-0.245^{* * *}$ & $-0.008^{* * *}$ & $3 \%$ & $-0.237^{* * *}$ & $97 \%$ \\
\hline $\begin{array}{l}\text { Model } d \text { : Industry } \\
\text { (20 categories) }\end{array}$ & $-0.245^{* * *}$ & $-0.007^{* * *}$ & $3 \%$ & $-0.238^{* * *}$ & $97 \%$ \\
\hline $\begin{array}{l}\text { Model } e \text { : Occupation } \\
\text { (42 categories) }\end{array}$ & $-0.245^{* * *}$ & $-0.064^{* * *}$ & $26 \%$ & $-0.181^{* * *}$ & $74 \%$ \\
\hline $\begin{array}{l}\text { Model } f: \text { Fully speci- } \\
\text { fied }\end{array}$ & $-0.245^{* * *}$ & $-0.117^{* * *}$ & $48 \%$ & $-0.127^{* * *}$ & $52 \%$ \\
\hline \multicolumn{6}{|l|}{$N=811,130$} \\
\hline $\begin{array}{l}\text { Model } g \text { : Fully speci- } \\
\quad \text { fied }(<=45)\end{array}$ & $-0.238^{* * *}$ & $-0.138^{* * *}$ & $58 \%$ & $-0.101^{* * *}$ & $42 \%$ \\
\hline \multicolumn{6}{|l|}{$N=480,585$} \\
\hline $\begin{array}{l}\text { Model } h \text { : Fully speci- } \\
\quad \text { fied }(>45)\end{array}$ & $-0.231^{* * *}$ & $-0.067^{* * *}$ & $29 \%$ & $-0.164^{* * *}$ & $71 \%$ \\
\hline$N=330,545$ & & & & & \\
\hline
\end{tabular}

Source: 2011 National Household Survey. ${ }^{*} \mathrm{P} \leq .05 ;{ }^{* *} \mathrm{P} \leq .01 ;{ }^{* * *} \mathrm{P} \leq .001$. Sample includes those with university degrees, over the age of 25 , with annual incomes greater than $\$ 1.00$. The sample excludes those with law or medical degrees, non-permanent residents, and those residing in the Northwest Territories, the Yukon, or Nunavut. Sample sizes for models 1 through 6 are identical. + Socio-demographic controls include categorical age, marital status, presence of children in the household, a quartic of potential experience (Mincer, Mincer $^{\wedge} 2$, Mincer $^{\wedge} 3$, Mincer $^{\wedge} 4$ ), marital status, province of residence, urban residence, degree type, works as professor, knowledge of official language, aboriginal status, visible minority, immigrant, and foreign-earned degree. 
Table 7. Decomposition of Gender Wage Gap for all University Graduates by Age Group

\begin{tabular}{|c|c|c|c|}
\hline & $\begin{array}{c}\text { Fully } \\
\text { Specified }\end{array}$ & $\begin{array}{c}\text { Fully } \\
\text { Specified } \\
(\leq 45)\end{array}$ & $\begin{array}{c}\text { Fully } \\
\text { Specified } \\
(>45)\end{array}$ \\
\hline Raw Wage Gap & $-0.245^{* * *}$ & $-0.238^{* * *}$ & $-0.231^{* * *}$ \\
\hline Differences in Characteristics & $-0.117^{* * *}$ & $-0.138^{* * *}$ & $-0.067^{* * *}$ \\
\hline Field of study (32 categories) & 0.003 & -0.002 & $0.014^{* * *}$ \\
\hline Age & $-0.008^{* *}$ & -0.002 & $-0.004^{*}$ \\
\hline Experience & $-0.006^{*}$ & $-0.016^{* * *}$ & $0.023^{* * *}$ \\
\hline Marital status & 0.000 & 0.000 & 0.001 \\
\hline Young children $(<15)$ & $-0.000^{* * *}$ & $-0.001^{* * *}$ & 0.000 \\
\hline Geography & $-0.004^{* * *}$ & $-0.004^{* * *}$ & $-0.004^{* * *}$ \\
\hline Self-employed & $0.026^{* * *}$ & $0.015^{* * *}$ & $0.035^{* * *}$ \\
\hline Master's degree & $-0.002^{* * *}$ & $-0.001^{* * *}$ & $-0.001^{* * *}$ \\
\hline Doctorate & $-0.004^{* * *}$ & $-0.002^{* * *}$ & $-0.005^{* * *}$ \\
\hline Professor & $-0.000^{* * *}$ & $-0.000^{*}$ & $-0.001^{* *}$ \\
\hline Hours worked & $-0.071^{* * *}$ & $-0.072^{* * *}$ & $-0.072^{* * *}$ \\
\hline Ethno-linguistic characteristics & $0.008^{* * *}$ & $0.009^{* * *}$ & $0.006^{* * *}$ \\
\hline Foreign degree & $0.008^{* * *}$ & $0.007^{* * *}$ & $0.008^{* * *}$ \\
\hline Industry (20 categories) & $-0.036^{* * *}$ & $-0.039^{* * *}$ & $-0.034^{* * *}$ \\
\hline Occupation (42 categories) & $-0.031^{* * *}$ & $-0.029^{* * *}$ & $-0.033^{* * *}$ \\
\hline Differences in Returns to Characteristics & $-0.127^{* * *}$ & $-0.101^{* * *}$ & $-0.164^{* * *}$ \\
\hline Field of study (32 categories) & $-0.041^{* * *}$ & $0.073^{* * *}$ & $-0.127^{* * *}$ \\
\hline Age & 0.000 & 0.025 & -0.038 \\
\hline Experience & $-0.109^{* *}$ & $-0.134^{* * *}$ & 0.436 \\
\hline Marital status & $-0.079^{* * *}$ & $-0.044^{* * *}$ & $-0.132^{* * *}$ \\
\hline Young children $(<15)$ & $-0.027^{* * *}$ & $-0.059^{* * *}$ & -0.002 \\
\hline Geography & $-0.051^{* * *}$ & -0.019 & $-0.061^{* * *}$ \\
\hline Self-employed & $0.005^{* *}$ & 0.001 & $0.011^{* * *}$ \\
\hline Master's degree & $0.006^{* * *}$ & -0.001 & $0.014^{* * *}$ \\
\hline Doctorate & $0.002^{*}$ & 0.000 & $0.005^{* *}$ \\
\hline Professor & $-0.004^{* * *}$ & $-0.002^{* * *}$ & $-0.005^{* * *}$ \\
\hline Hours worked & $0.236^{* * *}$ & $0.286^{* * *}$ & $0.197^{* * *}$ \\
\hline Ethno-linguistic characteristics & $0.035^{* * *}$ & $0.030^{* * *}$ & $0.040^{* * * *}$ \\
\hline Foreign degree & 0.000 & -0.001 & 0.000 \\
\hline Industry (20 categories) & $-0.034^{* * *}$ & $-0.054^{* * *}$ & -0.023 \\
\hline Occupation (40 categories) & $-0.077^{* * *}$ & $-0.128^{* * *}$ & $-0.040^{*}$ \\
\hline Constant & 0.010 & $-0.074^{*}$ & -0.437 \\
\hline $\mathrm{N}$ & 811,130 & 480,585 & 330,545 \\
\hline
\end{tabular}

Source: 2011 National Household Survey. ${ }^{*} \mathrm{P} \leq .05 ;{ }^{* *} \mathrm{P} \leq .01 ;{ }^{* * *} \mathrm{P} \leq .001$. Sample includes those with university degrees, over the age of 25 , with annual incomes greater than $\$ 1.00$. The sample excludes those with law or medical degrees, non-permanent residents, and those residing in the Northwest Territories, the Yukon, or Nunavut. 


\section{Discussion and Conclusion}

In recent years, there has been growing interest in the employment outcomes and earnings of those with postgraduate degrees. While both the federal and provincial governments have made significant investments to encourage enrolment in postgraduate education (Auriol, 2010; Hall \& Arnold, 2013; Industry Canada, 2002; Wiggers et al., 2011), questions have been raised regarding the economic outcomes of those who pursue higher education (Cyranoski et. al., 2011; Economist, 2010; Edge \& Munroe, 2015; Fullick, 2015). This study finds large returns for postgraduate education in Canada in both younger and older cohorts. Previous studies have found relatively modest unadjusted wage premiums for completing a doctoral degree over a master's degree, relative to the much larger wage advantage for completing a master's degree over a bachelor's degree (AUCC, 2011; Bayard \& Greenlee, 2009; Ferguson \& Wang, 2014). I find that the adjusted wage advantage for completing a doctoral degree is more than double the wage advantage for completing a master's degree, relative to a bachelor's degree (Table 3). However, there are important differences by field of study. The postgraduate wage premium is significantly lower for both men and women in humanities and much larger in business, management, and public administration. Women also have smaller postgraduate wage premiums in visual and performing arts and communication, physical and life sciences and architecture, as well as engineering and related fields. The finding that postgraduate wage premiums are lower for both men and women in the humanities is consistent with literature that has argued that humanities programs may not provide the knowledge or skills employers demand or value in the current labour market (Fenesi \& Sana, 2015).

This study has also contributed to the larger gender wage gap literature by exploring whether women's movement into postgraduate education has helped narrow the gender wage gap. Over the last few decades, women have made significant gains in educational attainment, which has helped narrow the gender wage gap at the aggregate level (Baker \& Drolet, 2010; Fortin \& Huberman, 2002; Frenette \& Coulombe, 2007). However, few studies have explored whether the gender wage gap is smaller at the postgraduate level. I find that the gender wage gap for university graduates is smaller at the master's level but not at the doctoral level (Table 5). This is more pronounced for older women with master's degrees. One explanation may be a greater concentration of women with master's degrees in Canada's public sector, where higher rates of unionization, more rigid wagesetting practices, less discretionary pay, and more firmly entrenched equality legislation help reduce wage inequality (Baker \& Fortin, 2004; Hou \& Coulombe, 2010; Mandel \& Semyonov, 2014; Waite \& Denier, 2015). Interestingly, holding a doctoral degree does not appear to be the great equalizer of the gender wage gap, as suggested by previous literature (Ferguson \& Wang, 2014).

The unexplained wage gap is smaller for the younger group than the older group. As women age and acquire more work experience, they are also exposed to more mechanisms that could potentially lead to greater wage disadvantage-for example, gender differences in workplace training, promotions, or discretionary wage-setting practices. These are often more difficult to control using standard wage-determination models and would result in a larger unexplained wage gap for older women (Rodgers, 2006). This study also found that differences in field of study explain far less of the gender wage gap than occupation. 
This suggests that women's choice of fields of study has, at least in the past, played a smaller role in explaining the gender wage gap than occupational sorting after graduation. Industry of employment also had a smaller effect than occupation. Taken together, these show that although women have made significant gains in educational attainment and the gender desegregation of some traditionally male fields of study, gender wage gaps persist for both younger and older cohorts. Differences in hours worked and occupation continue to play a significant role in women's disadvantage.

Other considerations that I have not addressed here include tuition fees, forgone wages, and other opportunity costs that come with postgraduate education. These can be significant, especially for those completing doctoral degrees. The government's investments in scholarships and fellowships have helped offset these costs, but only for the select few who are lucky enough to receive this assistance. Although the unadjusted (Table 2) and adjusted (Table 3) wage premiums for completing a postgraduate degree are relatively large, it may take many years to compensate for the foregone wages and other costs of obtaining a postgraduate degree. Postgraduate degrees in business, management, and administration will likely pay off more quickly than in other fields. Unfortunately, the opportunity costs and foregone wages in some fields, such as humanities, may be so great and the returns so minimal that they never pay off.

\section{Acknowledgements}

I would like to thank Michael R. Smith, Eran Shor, Thomas Soehl, Céline Le Bourdais, and the anonymous reviewers for their feedback on earlier versions of this paper. I also thank Anthony Lombardi and Dr. Rochelle Côte for assisting with the translation of the abstract. The Social Sciences and Humanities Research Council of Canada (SSHRC) provided doctoral funding for this project. The analysis in this paper was conducted at the Québec Interuniversity Centre for Social Statistics and Memorial University's Research Data Centre, both of which are part of the Canadian Research Data Centre Network (CRDCN). The services and activities provided by these labs are made possible by the financial or in-kind support of the SSHRC, the Canadian Institutes of Health Research, the Canada Foundation for Innovation, Statistics Canada, the Fonds de recherche du Québec - Société et culture, and participating universities. The views expressed in this paper are those of the author and not necessarily those of the CRDCN or its partners.

\section{References}

Association of Universities and Colleges of Canada (AUCC). (2011). Trends in higher education: Volume 1 - enrolment. Ottawa, ON: Author.

Auriol, L. (2010). Careers of doctorate holders: Employment and mobility patterns. Organisation for Economic Co-operation and Development Science, Technology and Industry Working Papers. Paris, France: OECD.

Baker, L. C. (1996). Differences in earnings between male and female physicians. New England Journal of Medicine, 334, 960-964.

Baker, M., Benjamin D., Desaulniers A., \& Grant M. (1995). The distribution of the male/female earnings differential, 1970-1990. Canadian Journal of Economics, 28(3), 479-501. 
Baker, M., \& Drolet M. (2010). A new view of the male/female pay gap. Canadian Public Policy, 36(4), 429-464.

Baker, M., \& Fortin, M. (2004). Comparable worth in a decentralized labour market: The case of Ontario. Canadian Journal of Economics, 37(4), 850-878.

Bayard, J., \& Greenlee, E. (2009). Graduating in Canada: Profile, labour market outcomes and student debt of the class of 2005. Culture, Tourism, and the Centre for Education Statistics Division, Statistics Canada (Cat. No. 81-595-M No. 074). Ottawa, ON: Statistics Canada.

Beaudry, P., \& Green, D. (2000). Cohort patterns in Canadian earnings: Assessing the role of skill premia in inequality trends. Canadian Journal of Economics, 33(4), 907-936.

Becker, G. (1964). Human capital: A theoretical and empirical analysis, with special reference to education. Chicago, IL: University of Chicago Press.

Blau, F. D., \& Kahn, L. M. (2000). Gender differences in pay. Journal of Economic Perspectives, 14(4), 75-99.

Blickenstaff, J. C. (2005). Women and science careers: Leaky pipeline or gender filter? Gender and Education, 17(4), 369-386.

Blinder, A. S. (1973). Wage discrimination: Reduced form and structural estimates. Journal of Human Resources, 8(4), 436-455.

Boudarbat, B., \& Connolly, M. (2013). The gender wage gap among recent postsecondary graduates in Canada: A distributional approach. Canadian Journal of Economics, 46(3), 1037-1065.

Boudarbat, B., Lemieux, T., \& Riddell, W. C. (2010). The evolution of the returns to human capital in Canada, 1980-2005. Canadian Public Policy, 36(1), 63-89.

Brown, L., Prentice S., \& Troutt, E. (2007, May). Sex and salaries at the University of Manitoba: Systematic discrimination in a Canadian university? Paper presented at the Canadian Employment Research Forum, Halifax, NS.

Budig, M. J., \& England, P. (2001). The wage penalty for motherhood. American Sociological Review, 66, 204-225.

Budig, M. J., \& Hodges, M. J. (2010). Differences in disadvantage: Variation in the motherhood penalty across white women's earnings distribution. American Sociological Review, 75(5), 705-728.

Christie, P., \& Shannon, M. (2001). Educational attainment and the gender wage gap: Evidence from the 1986 and 1991 Canadian censuses. Economics of Education Review, $20,165-180$.

Ci, W., Frenette, M., \& Morissette, R. (2016). Do layoffs increase transitions to postsecondary education among adults? Statistics Canada Analytical Studies Branch Paper Series (Catalogue number 11Foo19M No.380). Ottawa, ON: Statistics Canada.

Connolly, S., \& Holdcroft, A. (2006). The pay gap for women in medicine and academic medicine: An analysis of the WAM database. London, UK: British Medical Association. 
Cyranoski, D., Gilbert, N., Ledford, H., Nayar, A., \& Yahira, M. (2011). The PhD factory: The world is producing more PhDs than ever before. Is it time to stop? Nature, 472, 276-279.

Desjardins, L., \& King D. (2011). Expectations and labour market outcomes of doctoral graduates from Canadian universities. Culture, Tourism, and the Centre for Education Statistics Division, Statistics Canada (Cat. No. 81-595-M No. 089). Ottawa, ON: Statistics Canada.

Dinovitzer, R. (2006). Social capital and constraints on legal careers. Law \& Society Review, 4O(2), 445-480.

Dinovitzer, R. (2011). The financial rewards of elite status in the legal profession. Law \& Society Inquiry, 36(4), 971-998.

Dinovitzer, R., \& Hagan, J. (2006). Lawyers on the move: The consequences of mobility for legal careers. International Journal of the Legal Profession, 13(2), 119-135.

Doucet, C., Durand, C., \& Smith, M. R. (2008). Who gets market supplements? Gender differences within a large Canadian university. Canadian Journal of Higher Education, 38(1), 67-103.

Doucet, C., Smith, M. R., \& Durand, C. (2012). Pay structure, female representation and the gender pay gap among university professors. Relations industrielles / Industrial Relations, 67(1), 51-75.

Drolet, M. (2002). New evidence on gender pay differentials: Does measurement matter? Canadian Public Policy, 28(1), 1-16.

Drolet, M. (2009). The gender pay gap for private sector employees in Canada and Britain. IZA Working Paper Series, discussion paper no. 3957. Bonn, Germany: Institute for the Study of Labor.

Economist. (2010, December 16). The disposable academic: Why doing a PhD is often a waste of time. Retrieved from http://www.economist.com/node/17723223

Edge, J., \& Munro, D. (2015). Inside and outside the academy: Valuing and Preparing PhDs for careers. Ottawa, ON: The Conference Board of Canada.

Fenesi, B., \& Sana, F. (2015). What is your degree worth? The relationship between post-secondary programs and employment outcomes. Canadian Journal of Higher Education, 45(4), 383-399.

Ferguson, S. J., \& Wang, S. (2014). Graduating in Canada: Profile, labour market outcomes and student debt of the class of 2009-2010. Culture, Tourism and the Centre for Education Statistics: Research Papers (Cat. No. 81-595-M-No. 2014101). Ottawa, ON: Statistics Canada.

Ferrao, V. (2010). Paid work. Women in Canada: A gender-based statistical report by Statistics Canada. (Cat. No. 89-503-X). Ottawa, ON: Statistics Canada.

Finnie, R., \& Frenette, M. (2003). Earning differences by major field of study: Evidence from three cohorts of recent Canadian graduates. Economics of Education Review, 22, 179-192. 
Finnie, R., \& Wannell, T. (2004). Evolution of the gender earnings gap among Canadian university graduates. Applied Economics, 36(17), 1967-1978.

Fortin, N., \& Huberman, M. (2002). Occupational gender segregation and women's wages in Canada: An historical perspective. Canadian Public Policy, 28, S11-S39.

Fortin, N., \& Schirle, T. (2006). Gender dimensions of changes in earnings inequality in Canada. In D. A. Green \& J. R. Kesselman (Eds.), Dimensions of inequality in Canada (pp. 307-346). Vancouver, BC. UBC Press.

Frenette, M., \& Coulombe, C. (2007). Has higher education among young women substantially reduced the gender gap in employment and earnings? Statistics Canada Analytics Studies Branch Research Paper Series (Cat. No. 11Foo19MIE - No. 301). Ottawa, ON: Statistics Canada.

Frenette, M., \& Frank, K. (2016). Earnings of postsecondary graduates by detailed field of study. Economic Insights (Cat. No. 11-626-x). Ottawa, ON: Statistics Canada.

Fullick, M. (2015, March 25). PhD “overproduction" is not new and faculty retirements won't solve it. University Affairs. Retrieved from http://www.universityaffairs.ca/ opinion/speculative-diction/phd-overproduction-is-not-new-and-faculty-retirementswont-solve-it/

Guppy, N. (1989). Pay equity in Canadian universities: 1972-73 and 1985-86. Canadian Review of Sociology and Anthropology, 26(5), 743-758.

Hall, F., \& Arnold, H. (2013). Intentions for and outcomes following a decade of government investment in graduate education. Toronto, ON: Higher Education Quality Council of Ontario.

Hodges, M., \& Budig, M. (2010). Who gets the daddy bonus? Organizational hegemonic masculinity and the impact of fatherhood on earnings. Gender \& Society, 24, 717-745.

Hou, F., \& Coulombe, S. (2010). Earnings gaps for Canadian-born visible minorities in the public and private sectors. Canadian Public Policy, 36(1), 29-43.

Industry Canada. (2002). Achieving excellence: Investing in people, knowledge and opportunities. Canada's Innovation Strategy. Ottawa, ON: Government of Canada. Retrieved from http://publications.gc.ca/collections/Collection/C2-596-2001E.pdf

Ipsos. (2016). Financial optimism generational tracking. Ipsos Public Affairs Report. Toronto, ON: Author.

Jann, B. (2008). The Blinder-Oaxaca decomposition for linear regression models. The Stata Journal, 8(4), 453-479.

Kay, F., Masuch, C., \& Curry, P. (2004). Turning points and transitions: Women's careers in the legal profession. A longitudinal survey of Ontario lawyers 1990-2002. Toronto, ON: Law Society of Upper Canada.

Killewald, A. (2012). A reconsideration of the fatherhood premium: Marriage, coresidence, biology and fathers' wages. American Sociological Review, 78(1), 96-116.

Killewald, A., \& Gough, M. (2013). Does specialization explain marriage penalties and premiums? American Sociological Review, 78, 477-502. 
King, D. (2008). Doctoral graduates in Canada: Findings from the Survey of Earned Doctorates, 2004/2005. Culture, Tourism, and the Centre for Education Statistics Division, Statistics Canada (Cat. No. 81-595-M No. 065). Ottawa, ON: Statistics Canada.

King, D., Eisl-Culkin, J., \& Desjardins, L. (2008). Doctoral graduates in Canada: Findings from the Survey of Earned Doctorates, 2005/2006. Culture, Tourism, and the Centre for Education Statistics Division, Statistics Canada (Cat. No. 81-595-M No. 069). Ottawa, ON: Statistics Canada.

Lemieux, T. (2006). The "Mincer equation" thirty years after schooling, experience, and earnings. In S. Grossbord (Ed.), Jacob Mincer: A pioneer of modern labor economics (pp. 127-145). Secaucus, NJ: Springer.

Mandel, H., \& Semyonov, M. (2014). Gender pay gap and employment sector: Sources of earnings disparities in the United States, 1970-2010. Demography, 15, 1597-1618.

McMullen, K., Gilmore, J., \& Le Petit, C. (2010). Women in non-traditional occupations and fields of study. Education Matters 7.1 (Cat. No. 81-004-XE). Ottawa, ON: Statistics Canada.

Miller, L. T., Middaugh, C., \& Broniewicz, T. (2014). Outcomes of doctoral program graduates: Pilot test of a strategy to measure outcomes using exit and alumni surveys. Toronto, ON: Higher Education Quality Council of Ontario.

Morissette, R., Hou, F., \& Schellenberg, G. (2015). Full-time employment, 1976 to 2014. Statistics Canada Social Analysis and Modelling Division (Cat. No. 11-626-x No. 049). Ottawa, ON: Statistics Canada.

Murphy, K., \& Welch, F. (1990). Empirical age-earnings profiles. Journal of Labor Economics, 8(2), 202-229.

Oaxaca, R. (1973). Male-female wage differentials in urban labor markets. International Economic Review, 14(3), 693-709.

Ornstein, M., \& Stewart, P. (1996). Gender and faculty pay in Canada. Canadian Journal of Sociology, 21, 461-481.

Ornstein, M., Stewart, P., \& Drakich, J. (1998). The status of women faculty in Canadian universities. Education Quarterly Review, 5(2), 1-75.

Ornstein, M., Stewart, P., \& Drakich, J. (2007). Promotion at Canadian universities: The intersection of gender, discipline, and institution. Canadian Journal of Higher Education, 37(3), 1-25.

Pedersen, H. S. (2014). New doctoral graduates in the knowledge economy: Trends and key issues. Journal of Higher Education Policy Management, 36(6), 632-645.

Postsecondary Student Information System (PSIS). (2016a). University degrees, diplomas and certificates granted, by program level, classification of instructional programs, primary groupings (CIP_PG) and sex. Table Number: 477-0014. Ottawa, ON: Statistics Canada.

Postsecondary Student Information System (PSIS). (2016b). University enrolments, by registration status, program level, classification of instructional programs, primary groupings (CIP_PG) and sex. Table Number: 477-0013. Ottawa, ON: Statistics Canada. 
Robson, K., \& Wallace, J.E. (2001). Gendered inequalities in earnings: A study of Canadian lawyers. Canadian Review of Sociology and Anthropology, 38(1), 75-95.

Rodgers, W. M. (2006). Handbook on the economics of discrimination. Northampton, MA: Edward Elgar Publishing.

Sussman, D., \& Yssaad, L. (2005). The rising profile of women academics. Perspectives on Labour and Income, 6(2). Statistics Canada, cat. no. 75-001-XIE. Retrieved from http://www.statcan.gc.ca/pub/75-001-x/10205/4168716-eng.htm

Turcotte, M. (2011). Women and education. Statistics Canada, cat. no. 89-503-X. Retrieved from http://www.statcan.gc.ca/pub/89-503-x/2010001/article/11542-eng. htm

Waite, S., \& Denier, N. (2015). Gay pay for straight work: Mechanisms generating disadvantage. Gender \& Society, 29(4), 561-588.

Waldfogel, J. (1998). Understandings the "family gap" in pay for women with children. Journal of Economic Perspectives, 12, 137-156.

Warman, C., Woolley, F., \& Worswick, C. (2010). The evolution of male-female earnings in Canadian universities, 1970-2001. Canadian Journal of Economics, 43(1), 347-372.

Weeks, W. B., \& Wallace, A. E. (2007a). Gender differences in dermatologists' annual incomes. Cutis, 8o, 1696-6701.

Weeks, W. B., \& Wallace, A. E. (2007b). Gender differences in ophthalmologists' annual incomes. Ophthalmology, 114(9), 1696-1701.

Wiggers, R., Lennon, M. C., \& Frank, K. (2011). Expanding opportunities for graduate studies: the recent experience of Ontario. Toronto, ON: Higher Education Quality Council of Ontario.

Zhang, X. (2009). Earnings of women with and without children. Perspectives on Labour and Income, 10(3), 1-28.

\section{Notes}

1. During the same period, part-time enrolment in master's programs changed very little and parttime enrolment in doctoral programs declined slightly.

2. The number of postgraduate degrees granted is lower than enrolment because of attrition, which is greater at the doctoral level (Hall \& Arnold, 2014; King, 2008).

3. Two in five foreign-earned degrees were received in the United States. Other top countries were the United Kingdom, France, and China (King, Eisl-Culkin \& Desjardins, 2008).

4. The response rate of the 2007/2008 Survey of Earned Doctorates was 51\%. The response rate of the 2009/2010 National Graduate Survey was 49.1\%.

5. Sensitivity models reveal some difference when excluding those over the age of 64; however, there is nothing to suggest the conclusions in this paper are not robust.

6. I drop those with employment income less than $\$ 1.00$.

7. This refers to the hours worked in the previous week, rather than average hours worked in the year for which earnings information was available. I impute the mean hours of full-time work 
for those who report working mostly full-time in the previous year but who worked few hours in the previous week.

8. Sensitivity models isolating only those working full-time showed very little differences in the estimates. In some cases, postgraduate premiums increased in these models.

9. The standard quadratic Mincer equation (age - years of education - 5) underestimates wage growth for young workers and predicts too much of a decline in earnings for workers with greater than 25 years of experience (Lemieux, 2006).

10. One limitation of the Mincer proxy is its inability to account for periods of part-time employment and/or absences from the labour market. This may be a source of bias for women, who will have more absences from the labour market for childbearing than men. This bias will be reduced by controlling for the presence of children.

11. The two-digit series have 49 categories. There were 32 usable categories in the working sample.

12. Business professors do generally earn more than professors in other fields, but they still do not earn multi-million-dollar salaries, like some corporate executives.

13. Complete models can be found in Appendix Table B.

14. Heckman models were run in a variety of ways to test for sample selection bias, including the use of different exclusion restrictions. In some cases, the estimates changed by a fraction of a percent, but all models indicate that the OLS estimates are reliable.

15. The NHS does not collect information on public sector versus private sector employment; however, it is possible to make some inferences from the industry of employment and the NOC-S minor occupation classifications.

16. This finding does not appear to be driven by the more highly disaggregated occupation variable. Sensitivity models using 10 broad occupations reveal that occupation independently explained roughly four times more than field of study and industry of employment. In the fully specified model, broad occupation also explained more of the wage gap than field of study or industry of employment.

\section{Contact Information}

Sean Waite

Department of Sociology

Western University

swaite3@uwo.ca

Sean Waite is an assistant professor in the Department of Sociology at Western University. His research focuses on labour market stratification by gender and sexual orientation. For more information on Sean's research, please visit http://www.seanwaite.ca. 


\section{Appendices}

Table A. Primary Groupings of the Classification of Instructional Programs

\begin{tabular}{|c|c|}
\hline Primary Groupings & Examples \\
\hline Education & $\begin{array}{l}\text { Elementary and secondary school teaching } \\
\text { Elementary and middle school admin./principalship } \\
\text { Secondary school admin./principalship } \\
\text { Special education and teaching } \\
\text { Student counselling }\end{array}$ \\
\hline $\begin{array}{l}\text { Visual and performing arts, and } \\
\text { communications technologies }\end{array}$ & $\begin{array}{l}\text { Radio and television broadcasting; ballet/dance; acting } \\
\text { film/cinematography and video studies; graphic design; } \\
\text { fine art studies; music studies (music history, performance, } \\
\text { etc.) }\end{array}$ \\
\hline Humanities & $\begin{array}{l}\text { English language and literature; classical and ancient stud- } \\
\text { ies; philosophy and religious studies; history; French } \\
\text { language and literature }\end{array}$ \\
\hline $\begin{array}{l}\text { Social and behavioural sciences } \\
\text { and law** }\end{array}$ & $\begin{array}{l}\text { Area, ethnic, cultural, gender and group studies; media stud- } \\
\text { ies } \\
\text { broadcast journalism; public relations; psychology; econom- } \\
\text { ics; sociology; criminology; sustainability studies } \\
\text { cultural studies; legal studies (excluding law degrees) }\end{array}$ \\
\hline $\begin{array}{l}\text { Business, management, and } \\
\text { public administration }\end{array}$ & Accounting; marketing; e-commerce; banking and finance \\
\hline $\begin{array}{l}\text { Physical and life sciences and } \\
\text { technologies }\end{array}$ & $\begin{array}{l}\text { Biological and biomedical sciences; natural sciences; nutri- } \\
\text { tional sciences; human biology; marine sciences }\end{array}$ \\
\hline $\begin{array}{l}\text { Mathematics, computer, and } \\
\text { information sciences }\end{array}$ & $\begin{array}{l}\text { Computer programming } \\
\text { Computer systems analyst } \\
\text { Library sciences } \\
\text { Mathematics and statistics }\end{array}$ \\
\hline $\begin{array}{l}\text { Architecture, engineering, and } \\
\text { related technologies }\end{array}$ & $\begin{array}{l}\text { Engineering (agricultural, chemical, civil, etc.) } \\
\text { Architecture } \\
\text { City/urban, community, and regional planning }\end{array}$ \\
\hline $\begin{array}{l}\text { Agriculture, natural resources, } \\
\text { and conservation }\end{array}$ & $\begin{array}{l}\text { Natural resource and conservation } \\
\text { Agricultural economics } \\
\text { Horticultural sciences } \\
\text { Agricultural soil microbiology }\end{array}$ \\
\hline Health* and related fields & $\begin{array}{l}\text { Parks, recreation, leisure, and fitness studies } \\
\text { Health professions (excluding medical degrees) } \\
\text { Kinesiology and exercise sciences }\end{array}$ \\
\hline $\begin{array}{l}\text { Personal, protective, and trans- } \\
\text { portation services }\end{array}$ & $\begin{array}{l}\text { Military science, leadership, and operational art } \\
\text { Air transportation }\end{array}$ \\
\hline
\end{tabular}

* Lawyers and doctors excluded from working sample. 


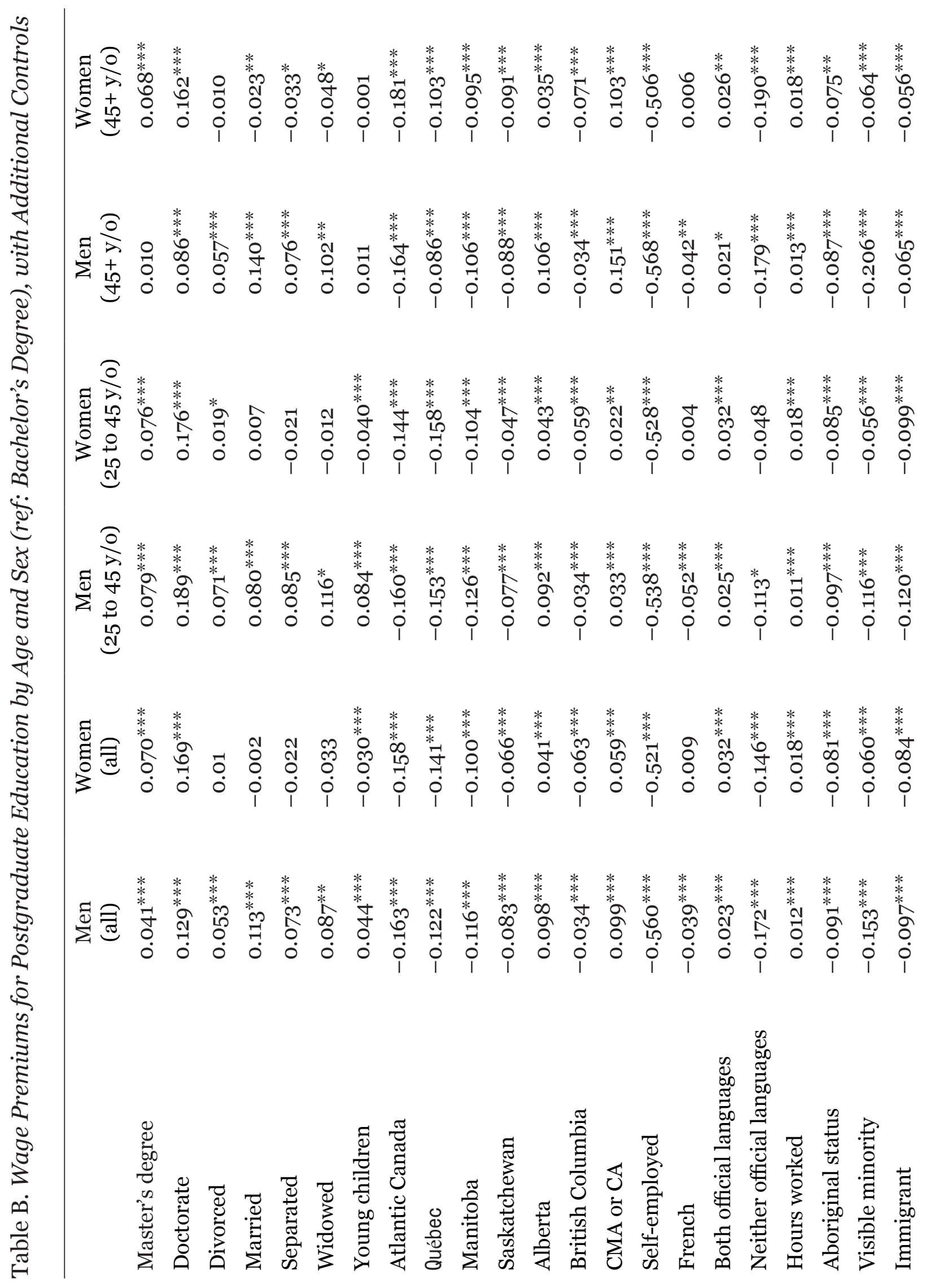




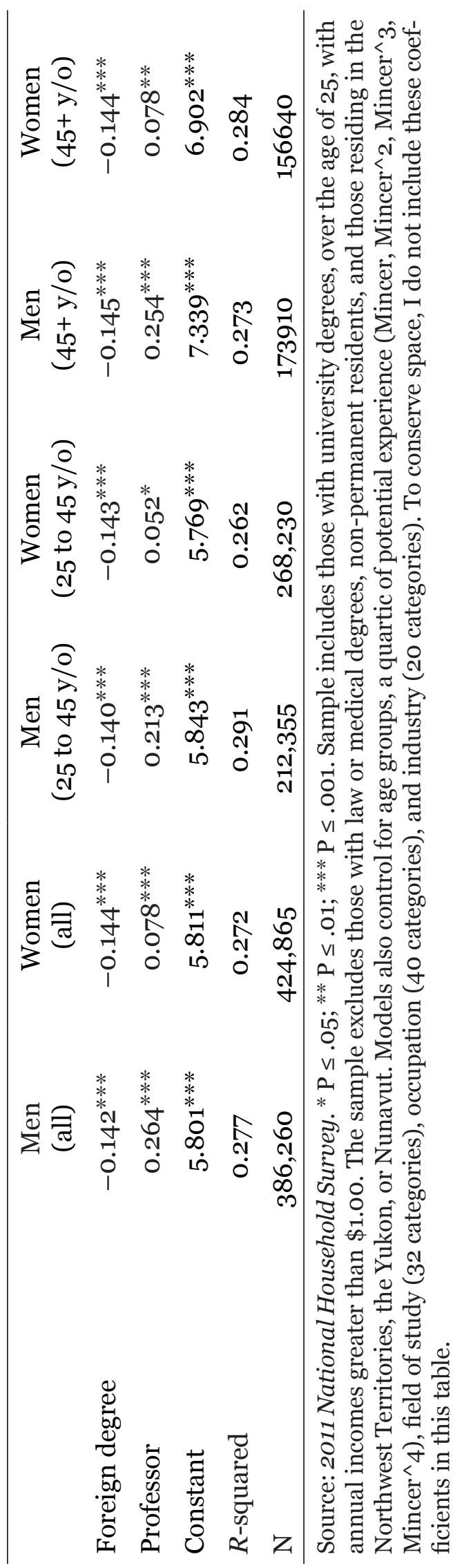




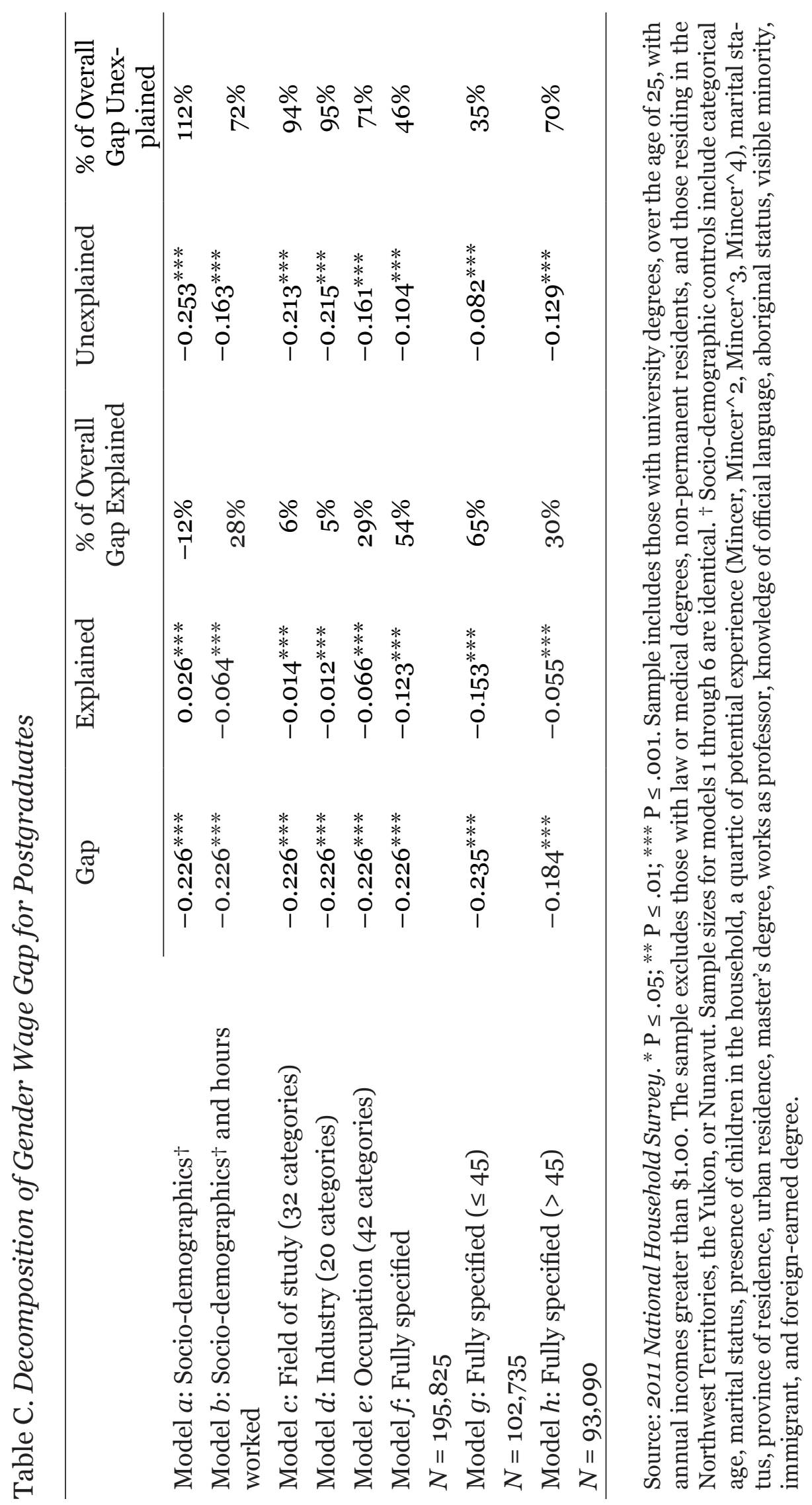


Table D. Decomposition of Gender Wage Gap for Postgraduates by Age Group

\begin{tabular}{|c|c|c|c|}
\hline & Fully Specified & $\begin{array}{l}\text { Fully Specified } \\
(\leq 45)\end{array}$ & $\begin{array}{l}\text { Fully Specified } \\
(>45)\end{array}$ \\
\hline Raw Wage Gap & $-0.226^{* * *}$ & $-0.235^{* * *}$ & $-0.184^{* * *}$ \\
\hline Differences in characteristics & $-0.123^{* * *}$ & $-0.153^{* * *}$ & $-0.055^{* * *}$ \\
\hline Field of study (32 categories) & 0.004 & -0.007 & 0.013 \\
\hline Age & $-0.014^{*}$ & -0.005 & -0.006 \\
\hline Experience & -0.012 & $-0.027^{* * *}$ & $0.027^{* * *}$ \\
\hline Marital status & 0.000 & 0.001 & -0.002 \\
\hline Young children $(<15)$ & 0.000 & 0.000 & -0.002 \\
\hline Geography & $-0.003^{* * *}$ & $-0.002^{* * *}$ & $-0.004^{* * *}$ \\
\hline Self-employed & $0.016^{* * *}$ & $0.006^{* * *}$ & $0.019^{* * *}$ \\
\hline Doctorate & $-0.006^{* * *}$ & $-0.004^{* * *}$ & $-0.007^{* * *}$ \\
\hline Professor & $-0.002^{* * *}$ & $-0.002^{* * *}$ & $-0.001^{* * *}$ \\
\hline Hours worked & $-0.063^{* * *}$ & $-0.071^{* * *}$ & $-0.055^{* * *}$ \\
\hline Ethno-linguistic characteristics & $0.018 * * *$ & $0.022^{* * *}$ & $0.013^{* * *}$ \\
\hline Foreign degree & $0.006^{* * *}$ & $0.005^{* * *}$ & $0.009^{* * *}$ \\
\hline Industry (20 categories) & $-0.027^{* * *}$ & $-0.031^{* * *}$ & $-0.024^{* * *}$ \\
\hline Occupation (40 categories) & $-0.039^{* * *}$ & $-0.038^{* * *}$ & $-0.034^{* * *}$ \\
\hline Differences in returns to characteristics & $-0.104^{* * *}$ & $-0.082^{* * *}$ & $-0.129^{* * *}$ \\
\hline Field of study (32 categories) & $-0.051^{* *}$ & $0.111^{* * *}$ & $-0.127^{* * *}$ \\
\hline Age & 0.043 & 0.047 & $-0.127^{* *}$ \\
\hline Experience & $-0.174^{*}$ & $-0.169^{* *}$ & 1.870 \\
\hline Marital status & $-0.068^{* * *}$ & $-0.036^{* * *}$ & $-0.099^{* * *}$ \\
\hline Young children $(<15)$ & $-0.018^{* * *}$ & $-0.048^{* * *}$ & -0.001 \\
\hline Geography & -0.042 & -0.009 & -0.049 \\
\hline Self-employed & $0.010^{* * * *}$ & 0.005 & $0.013^{*}$ \\
\hline Doctorate & -0.001 & -0.004 & 0.002 \\
\hline Professor & $-0.012^{* * *}$ & $-0.010^{* * *}$ & $-0.011^{* * *}$ \\
\hline Hours worked & $0.187^{* * *}$ & $0.245^{* * *}$ & $0.158^{* * *}$ \\
\hline Ethno-linguistic characteristics & $0.016^{*}$ & -0.001 & $0.036^{* *}$ \\
\hline Foreign degree & $0.011^{*}$ & $0.014^{*}$ & 0.007 \\
\hline Industry (20 categories) & $-0.041^{*}$ & $-0.080^{* * *}$ & -0.033 \\
\hline Occupation (40 categories & $-0.056^{* *}$ & $-0.106^{* * *}$ & -0.004 \\
\hline Constant & 0.091 & -0.042 & -1.765 \\
\hline$N$ & 195,825 & 102,735 & 93,090 \\
\hline
\end{tabular}

Source: 2011 National Household Survey. ${ }^{*} \mathrm{P} \leq .05 ;{ }^{* *} \mathrm{P} \leq .01 ;{ }^{* *} \mathrm{P} \leq .001$. Sample includes those with university degrees, over the age of 25 , with annual incomes greater than $\$ 1$.oo. The sample excludes those with law or medical degrees, non-permanent residents, and those residing in the Northwest Territories, the Yukon, or Nunavut. 